\title{
BIBLIOGRAPHY
}

\author{
Manuscripts \\ Aberdeen City Archives
}

Baillie Court: propinquity books, 1637-1797

American Philosophical Society, Philadelphia

APS, 361 5a2, records of the St Andrew's Society of Philadelphia

Pinney papers

\section{Bristol University Library}

DM41, West Indies MSS, Westerhall papers

DM78-7, West Indies papers

DM470, Society of Merchant Venturers of Bristol: books of proceedings, 1605-1900

DM1061, Papers of Captain David Duncomb

DM1781/BRA2630, West Indies MSS, sale of Belmont estate, Grenada

T-SK, Stirling of Keir papers

\section{Glasgow City Archives}

\section{Highland Council Archives, Inverness}

D456, Baillie of Dunain papers

Inverness Royal Academy minute book, 1798-1823

\section{Historical Society of Pennsylvania, Philadelphia}

462/Am.111, Orr, Dunlope \& Glenhome letterbook, 1767-69

1582/29B, Powell collection, papers of Alexander Johnston

1688/149.L.S, MacPherson family papers: correspondence

\section{Inverness Museum}

Letterbook of George Inglis, 1801-03

\section{Inverness Royal Academy}

A1, Directors' minute book, 1787-98

A2, Directors' minutes, 1787-1847

B1-2, Class registers

Jamaica Archives, Spanish Town

IB/II, Jamaica inventories 


\section{BIBLIOGRAPHY}

The National Archives, Public Record Office, Kew

CO71/1, Dominica, original correspondence: Board of Trade, 1770-76

CO71/2, Dominica, original correspondence: secretary of State, 1730-1801

CO71/26, Dominica, original correspondence

CO72/3, Dominica, entry books: letters to the secretary of State, 1770-79

CO72/6, Dominica, entry books: précis of correspondence, 1794-97

CO74/1, Dominica, sessional papers, minutes of the council, 1767-70

CO74/3, Dominica, sessional papers, minutes of the assembly, 1769-76

CO74/6A, Dominica, sessional papers: minutes of the council and assembly, $1786-90$

CO74/6B, Dominica, sessional papers: extracts of minutes of the council, $1771-91$

CO101/1-7, Grenada, original correspondence: Board of Trade

CO101/14, Grenada, original correspondence: Secretary of State, 1769-70

CO101/19, Grenada, original correspondence: Secretary of State, 1775-76

CO101/25, Grenada, original correspondence: Secretary of State, 1784

CO101/30-4, Grenada, original correspondence: Secretary of State

CO102/15-16, Grenada, entry books: letters from the Secretary of State

CO104/1-3, Grenada, sessional papers

CO106/1, Grenada, miscellanea: shipping returns 1764-67

CO106/9-12, Grenada, miscellanea: papers relating to the sale of lands in the Ceded Islands

CO142/31, Jamaica, miscellanea: list of landholders in the island of Jamaica, 1754

CO152/68, Leeward Islands, original correspondence

CO260/1, St Vincent, original correspondence: Board of Trade, 1773-78

CO260/7, St Vincent, original correspondence: Secretary of State, 1783-86

CO260/13, St Vincent, original correspondence: Secretary of State, 1794-96

CO261/6, St Vincent, entry books, précis of correspondence, 1794-97

CO263/1-3, St Vincent, sessional papers

CO263/21, St Vincent, sessional papers: minutes of the assembly, 1786-93

CO285/1, Tobago, original correspondence: Board of Trade, 1778-81

CO285/3-4, Tobago, original correspondence: Secretary of State

CO288/1-3, Tobago, sessional papers

CO318/8, West Indies, original correspondence: Secretary of State

CO441/10/9, Papers, correspondence and plans: Baillie

T71/266, 268, 273-6, 279-80, 284-5, 290-1, 299, 301, 305-6, 320-1, 323, slave registers, $1817-33$

\section{National Archives of Scotland, Edinburgh}

CS96, Court of Session, unextracted processes

GD1, Miscellaneous accessions

GD21, Cuninghame of Thornton muniments

GD22, Cunninghame-Graham papers

GD23, Bught papers

GD34, Abercairney papers 


\section{BIBLIOGRAPHY}

GD44, Gordon Castle muniments

GD51, Melville Castle muniments

GD121, Murthly Castle muniments

GD126, Balfour-Melville papers

GD128, Fraser-MacIntosh papers

GD160, Drummond Castle papers

GD205, Ogilvy of Inverquharity papers

GD224, Buccleuch papers

GD225, Leith Hall muniments

GD237/12, Macdouall of Garthland papers

GD248, Seafield muniments

GD267, Home of Wedderburn manuscripts

GD345, Grant of Monymusk muniments

National Library of Jamaica, Kingston

MS179, Letterbook of George Ferguson

MS287, Acts of the assembly of the island of Jamaica 1681-1791

MS375, Letters to Sir William Young and Alexander Gordon of Tobago

MS577, Letters of Charles Hamilton of Montego Bay

MS1066, Fotheringham indentures, 1788

MS1204, Fodringham indenture

MS1235, Lease for Moor Park plantation, St James's

MS1236, Conveyance of release of Tivoli estate

MS1655, Fyffe family letters, 1750-1821

\section{National Library of Scotland, Edinburgh}

MS17, 21, 22, 60, 1075, 3835, 3844, 6524, 9370, 14828, Melville papers

MS1284, Delvine papers, Grant of Ballindalloch

MS5513-15, 5538, 5555, 5704-5, 5599, Liston papers

MS8793-800, 8895-6, Alexander Houstoun \& Co. papers

MS10924-5, Graham of Airth papers, Jamaican papers

Map Library, EMAM.s. 5-7, J. Robertson, 'Map of the counties of Surrey,

Middlesex and Cornwall in the island of Jamaica', 1804

Acc. 11910, Haldane papers

\section{National Maritime Museum, Greenwich}

DOU/6, Papers of Admiral Sir James Douglas

University of Aberdeen, Special Collections and Archives

MS661, Letter collection: miscellaneous accessions

MS966/1-10, Letters of Lord Adam Gordon, 1783-95

MS1160, Gordon of Cairness papers

MS2070, Journal of Jonathan Troup, 1789-90

MS2226/1/-351, Taylor manuscripts

MS2769, Davidson \& Garden archive

MS3027, Journal of Jonathan Troup 


\section{BIBLIOGRAPHY}

MS3175, Duff House papers

MS3575, Papers of Murray families, 1753-1859

MS3652, Shand papers

\section{Printed primary sources}

Aberdeen Journal

Blackwood's Edinburgh Magazine

Calendar of state papers, colonial series, America and the West Indies

Edinburgh Almanack and Scots Register

Edinburgh Evening Courant

Edinburgh Review

Gentleman's Magazine

Gore's Liverpool Directory

Hansard's parliamentary history of England

House of Lords sessional papers (reprinted, New York: Oceana Publications, 1974)

Inverness Journal and Northern Advertiser

Journals of the House of Commons

Philosophical Transactions of the Royal Society

Scots Magazine

St. George's Chronicle and New Grenada Gazette

\section{Books and articles}

Addison, W. Innes, The matriculation albums of the University of Glasgow, from 1728 to 1858, Glasgow, 1913

Agnew, L. R. C., 'Scottish medical education', in C. D. O'Malley (ed.), The history of medical education, Los Angeles, 1970

Akenson, Donald H., If the Irish ran the world: Montserrat, 1630-1730, Liverpool, 1997

Anderson, Benedict, Imagined communities: Reflections on the origins and spread of nationalism, London and New York, 1991

Anderson, J., Prize essay on the state of society and knowledge in the Highlands of Scotland, Edinburgh, 1827

Anderson, P. J. (ed.), Officers and graduates of University and King's College, Aberdeen, 1495-1860, Aberdeen, 1893

Anderson, P. J. (ed.), Fasti Academiae Marischallanae Aberdonensis: Selections from the records of the Marischal College and University, 1593-1860, Aberdeen, 1898

Anderson, P. J. (ed.), Roll of alumni in arts of the University and King's College, Aberdeen, 1496-1860, Aberdeen, 1900

Anon., Considerations on the state of the sugar islands, and on the policy of enabling foreigners to lend money on real securities in those colonies, London, 1773 


\section{BIBLIOGRAPHY}

Anon., A plain state of the argument between Great Britain and her colonies, London, 1775

Anon., An account of the island of Jamaica, with reflections on the treatment, occupation and provisions of the slaves, Newcastle, 1788

Anon., A brief enquiry into the causes of, and conduct pursued by the colonial government, for quelling the insurrection in Grenada, London, 1796

Anon., 'Present state of West India affairs', Edinburgh Review, 28 (1817), 340-71

Anon., 'Strictures on an article in no. LVI of the Edinburgh Review, entitled "Present state of West India affairs", Blackwood's Edinburgh Magazine, 7, 2(1817), 41-6

Anon., The British poets, vol. 59: The poems of Grainger and Boyse, Chiswick, 1822

Anon., A catalogue of the graduates in the faculties of Arts, Divinity and Law in the University of Edinburgh since its foundation, Edinburgh, 1858

Anon., A view of the Merchants' House of Glasgow, Glasgow, 1866

Anon., List of graduates in medicine in the University of Edinburgh, from 1705-1866, Edinburgh, 1867

Anon., 'The rise of Glasgow's West Indian trade, 1793-1818', Three Banks Review, 51 (1961), 34-44

Anon., 'An early Glasgow-West Indian miscellany', Three Banks Review, 54 (1962), 29-38

Anon., Monumental inscriptions, chapel burial ground Inverness, Inverness, 1996

Armitage, David, 'The Scottish vision of empire: Intellectual origins of the Darien venture', in J. Robertson (ed.), A union for empire: Political thought and the Union of 1707, Cambridge, 1995

Armitage, David, 'Making the empire British: Scotland in the Atlantic world, 1542-1707', Past and Present, 155 (1997), 34-63

Armitage, David, 'Greater Britain: A useful category of historical analysis?', American Historical Review, 104, 2 (1999), 427-46

Armitage D., and Braddick, M. (eds), The British Atlantic world, 1500-1800, Basingstoke, 2002

Armytage, Frances, The freeport system in the British West Indies: A study in commercial policy, 1766-1822, London, 1953

Arnold, David (ed.), Imperial medicine and indigenous societies, Manchester, 1988

Atwood, Thomas, The history of the island of Dominica, London, 1791

Bailyn, Bernard, Voyagers to the west: A passage in the peopling of America on the eve of the revolution, London, 1987

Bailyn, Bernard, 'The idea of Atlantic history', Itinerario, 20 (1996), 19-44

Bailyn, B., and Morgan, P. D. (eds), Strangers within the realm: Cultural margins of the first British Empire, Chapel Hill, 1991

Barclay, H. F., A history of the Barclay family with pedigrees from 1067 to 1933, 3 vols, London, 1933 


\section{BIBLIOGRAPHY}

Baugh, Daniel A., British naval administration in the age of Walpole, Princeton, 1965

Bayly, C. A., Imperial meridian: The British Empire and the world, 1780-1830, London, 1989

Beckles, Hilary M., "Black men in white skins": The formation of a white proletariat in West Indian society', Journal of Imperial and Commonwealth History, 15, 1 (1986), 5-21

Beckles, H., and Shepherd, V. (eds), Caribbean slave society and economy, New York, 1991

Blackburn, Robin, The making of New World slavery: From the Baroque to the modern 1492-1800, London, 1997

Boney, A. D., The lost gardens of Glasgow University, London, 1988

Bowen, H. V., Elites, enterprise and the making of overseas empire, 1688-1775, Basingstoke, 1996

Bowen, H. V., 'British conceptions of global empire, 1756-83', Journal of Imperial and Commonwealth History, 26, 3 (1998), 1-27

Boyd, Walter, Letter to the creditors of the house of Boyd, Benfield 4 Co., London, 1800

Brathwaite, E., The development of Creole society in Jamaica, 1770-1820, Oxford, 1971

Brewer, J., The sinews of power: Money, war and the English state, 1688-1783, London, 1989

Brewer, J., and Porter R. (eds), Consumption and the world of goods, London, 1993

British parliamentary papers: Slave trade 87: Papers relating to negro apprenticeship slavery and the abolition of the slave trade, Shannon, 1969

Broadie, Alexander (ed.), The Scottish Enlightenment: An anthology, Edinburgh, 1997

Bryant, G. J., 'Scots in India in the eighteenth century', Scottish Historical Review, 64, 1 (1985), 22-41

Buettner, Elizabeth, 'Haggis in the Raj: Private and public celebrations of Scottishness in late imperial India', Scottish Historical Review, 81, 2 (2002), 212-39

Bull, Ida, 'Merchant households and their networks in eighteenth-century Trondheim', Continuity and Change, 17, 2 (2002), 213-31

Bumsted, J. M., The people's clearance: Highland emigration to British North America, 1770-1815, Edinburgh and Winnipeg, 1982

Burnard, Trevor, 'European migration to Jamaica, 1655-1780', William and Mary Quarterly, 53, 4 (1996), 769-96

Bush, Barbara, "White "ladies", coloured "favourites" and black "wenches": Some considerations on sex, race and class factors in social relations in white Creole society in the British Caribbean', Slavery and Abolition, 2 (1981), 245-62

Cage, R. A., The Scots abroad, London, 1985

Cain, P. J., and Hopkins, A. G., British imperialism, vol. 1: Innovation and expansion, 1688-1914, London, 1993 


\section{BIBLIOGRAPHY}

Calder, Angus, Revolutionary empire, New York, 1981

Callander, R. F., A pattern of landownership in Scotland, Finzean, 1987

Cameron, V. R. (ed.), Emigrants from Scotland to America, 1774-1775, Baltimore, 1965

Campbell, John, A political survey of Britain, being a series of reflections on the situation, lands, inhabitants, revenues, colonies, and commerce of this island, 2 vols, London, 1774

Campbell, R. H., 'An economic history of Scotland in the eighteenth century', Scottish Journal of Political Economy, 11 (1964), 17-24

Campbell, R. H., Scotland since 1707: The rise of an industrial society, Edinburgh, 1985

Canny, Nicholas (ed.), The Oxford history of the British Empire, vol. 1: The origins of empire, Oxford, 1998

Carmichael, A. C., Domestic manners and social conditions of the white, coloured and negro populations of the West Indies, London, 1833

Carrington, S. H. H., 'The American Revolution and the British West Indies' economy', Journal of Interdisciplinary History, 17, 4 (1987), 823-50

Cathcart, Alison, 'Patterns of kinship and clanship: The MacIntoshes of clan Chattan, 1291-1609', PhD thesis, University of Aberdeen, 2001

Checkland, S. G., 'Two Scottish West India liquidations after 1793', Scottish Journal of Political Economy, 4 (1957), 127-43

Checkland, S. G., 'Finance for the West Indies, 1780-1815', Economic History Review, 10 (1957), 461-9

Checkland, S. G., Scottish banking: A history, 1695-1973, Glasgow and London, 1975

Clayton, T. R., 'Sophistry, security and socio-political structures in the American Revolution; or, why Jamaica did not rebel', Historical Journal, 29, 2 (1986), 319-44

Chisholm, C., An essay on the malignant pestilential fever introduced into the West Indian islands from Boullam, London, 1801

Christie, O. F. (ed.), The diary of William Jones, 1777-1821, London, 1929

Clark, James, A treatise on the yellow fever, as it appeared in the island of Dominica in the years 1793-96, London, 1797

Clive, J. and Bailyn, B., 'England's cultural provinces: Scotland and America', William and Mary Quarterly, 11 (1954), 200-13

Clyde, D. F., Two centuries of health care in Dominica, New Delhi, 1980

Cochran, L. E., Scottish trade with Ireland in the eighteenth century, Edinburgh 1985

Colley, Linda, Britons: Forging the nation, 1707-1837, London, 1994

Collins, Dr, Practical rules for the management and treatment of negro slaves in the sugar colonies, 1803; Freeport, 1971

Comrie, J. D., History of Scottish medicine, London, 1927

Cooper, J. C., A Cooper family from north east Angus, Elmvale, 1992

Cope, S. R., Walter Boyd: A merchant banker in the age of Napoleon, London, 1983

Cope, Z., 'The private medical schools of London, 1746-1914', in F. N. L. Poynter (ed.), The evolution of medical education in Britain, Baltimore, 1966 


\section{BIBLIOGRAPHY}

Cowton, C. J., and O'Shaughnessy, A. J., 'Absentee control of sugar plantations in the British West Indies', Accounting and Business Research, 22, 85 (1991), $33-45$

Cox, Edward L., 'Fedon's Rebellion 1795-96: Causes and consequences', Journal of Negro History, 67, 1 (1982), 7-19

Craig, W. S., History of the Royal College of Physicians of Edinburgh, Oxford, 1976

Craton, Michael, Testing the chains: Resistance to slavery in the British West Indies, Ithaca, 1982

Craton, M., and Walvin, J., A Jamaican plantation: The history of Worthy Park, 1670-1970, London, 1970

Crosby, Alfred W., Ecological imperialism: The biological expansion of Europe, 900-1900, Cambridge, 1986

Cumberland, Richard, The West Indian: a comedy, London, 1771

Cundall, F. (ed.), Lady Nugent's journal, London, 1939

Dalzel, Archibald, The history of Dahomey: An inland kingdom of Africa, 1793; London, 1967

Dancer, Thomas, A short dissertation on the Jamaica Bath waters, Kingston, 1784

Darragh, J., 'The Catholic population of Scotland since the year 1680', Innes Review, 4 (1953), 49-59

Davis, Ralph, 'English foreign trade, 1700-1774', Economic History Review, 15, 2 (1962), 285-303

Davis, Ralph, The rise of the Atlantic economies, Ithaca, 1973

Devine, Thomas M., 'Glasgow colonial merchants and land, 1770-1815', in J. T. Ward and R. G. Wilson (eds), Land and industry: The landed estate and the industrial revolution, Newton Abbot, 1971

Devine, Thomas M., 'Transport problems of Glasgow-West India merchants in the American War of Independence, 1775-83', Transport History, 4, 3 (1971), 266-304

Devine, Thomas M., 'Sources of capital for the Glasgow tobacco trade, c. 1740-1780', Business History, 16, 2 (1974), 113-29

Devine, Thomas M., The tobacco lords: A study of the tobacco merchants of Glasgow and their trading activities, c. 1740-1790, Edinburgh, 1975

Devine, Thomas M., 'The colonial trades and industrial investment in Scotland, c. 1700-1815', Economic History Review, 29, 1 (1976), 1-13

Devine, Thomas M., 'An eighteenth-century business elite: Glasgow-West India merchants, c. 1750-1815', Scottish Historical Review, 57 (1978), 40-67

Devine, Thomas M., The transformation of rural Scotland: Social change and the agrarian economy, 1600-1815, Edinburgh, 1994

Devine, Thomas M., Clanship to crofters' war: The social transformation of the Scottish Highlands, Manchester, 1994

Devine, Thomas M., Scottish Nation 1700-2000, London, 1999

Devine, Thomas M., Scotland's empire, 1600-1815, London, 2003

Devine, Thomas M. (ed.), A Scottish firm in Virginia, 1767-1777, Edinburgh, 1984

Devine, Thomas M. (ed.), Improvement and Enlightenment, Edinburgh, 1989 


\section{BIBLIOGRAPHY}

Devine, Thomas M. (ed.), Scottish elites, Edinburgh, 1994

Devine, T. M., and Jackson, G. (eds), Glasgow, vol. 1: Beginnings to 1830, Manchester, 1995

Devine, T. M., and Mitchison R. (eds), People and society in Scotland, vol. 1: 1760-1830, Edinburgh, 1988

Devine, T. M., and Young, J. R. (eds), Eighteenth-century Scotland: New perspectives, East Linton, 1999

Dobson, David, Scottish emigration to colonial America, 1607-1785, Athens, GA, 1994

Dodgshon, R. A., Land and society in early Scotland, Oxford, 1981

Doig, A. et al., William Cullen and the eighteenth-century medical world, Edinburgh, 1993

Donald, Diana, The age of caricature: Satirical prints in the reign of George III, New Haven, 1996

Donaldson, Gordon, The Scots overseas, London, 1966

Donovan, R. K., 'Voices of distrust: The expression of anti-Catholic feeling in Scotland, 1778-81', Innes Review, 30 (1979), 62-76

Drescher, Seymour, Econocide: British slavery in the age of abolition, Pittsburgh, 1977

Dunn, Richard S., Sugar and slaves: The rise of the planter class in the English West Indies, 1624-1713, Chapel Hill, 1972

Dunn, Richard S., 'A tale of two plantations: Slave life at Mesopotamia in Jamaica and Mount Airy in Virginia', William and Mary Quarterly, 34, 1 (1977), 32-65

Durie, Alistair J., 'The markets for Scottish linen, 1730-1775', Scottish Historical Review, 52 (1973), 30-49

Durie, Alistair J., The Scottish linen industry, Edinburgh, 1979

Durie, Alistair J., The British Linen Company, 1745-75, Edinburgh, 1996

Dwyer, J. et al., New perspectives on the politics and culture of early modern Scotland, Edinburgh, 1982

Edwards, Bryan, The history, civil and commercial, of the British colonies in the West Indies, London, 1801, 1819

Eltis, David, The rise of African slavery in the Americas, Cambridge, 2000

Eltis, David et al., The trans-Atlantic slave trade: A database on CD-ROM, Cambridge, 1999

Evans, June, 'Africans/Caribbeans in Scotland: A socio-geographical study', PhD thesis, University of Edinburgh, 1996

Fagerstrom, Dalphy I., 'Scottish opinion and the American Revolution', William and Mary Quarterly, 11 (1954), 252-75

Farnie, Douglas A., 'The commercial empire of the Atlantic, 1607-1783', Economic History Review, 15, 2 (1962), 205-18

Ferguson, W., Scotland, 1689 to the present, Edinburgh, 1994

Feurtado, W. A., Official and other personages of Jamaica, from 1655 to 1790, Kingston, 1896

Flavell, Julie, "The school for modesty and humility": Colonial American youth in London and their parents, 1755-75', Historical Journal, 42, 2 (1999), 377-403 


\section{BIBLIOGRAPHY}

Forbes, E., An inaugural lecture on botany, considered as a science and a branch of medical education, London, 1843

Foster, J., Pedigree of the county families of Yorkshire, 3 vols, London, 1874

Fraser, W., Memoirs of the Maxwells of Pollock, Edinburgh, 1863

Fraser-MacIntosh, Charles (ed.), Letters of two centuries, chiefly connected with Inverness and the Highlands, from 1616 to 1815, Inverness, 1890

Fry, Michael, Patronage and principle, Aberdeen, 1987

Fry, Michael, The Dundas despotism, Edinburgh, 1992

Fry, Michael, Scottish empire, East Linton, 2001

Fryer, Linda G., 'Robert Barclay of Ury and East New Jersey', Northern Scotland, 15 (1995), 1-17

Fryer, P., Staying power: The history of black people in Britain, London, 1987

Games, Alison, Migration and the origins of the English Atlantic world, Cambridge, MA, 1999

Geggus, David, 'Yellow fever in the 1790s: The British army in occupied St Domingue', Medical History, 23, 1 (1979), 38-58

Geyer-Kordesch, J., 'Comparative difficulties: Scottish medical education in the European context, c. 1690-1830', in V. Nutton and R. Porter (eds), The history of medical education in Britain, Amsterdam, 1995

Gibb, Andrew D., Scottish empire, London, 1937

Goodyear, J. D., 'The sugar connection: A new perspective on the history of yellow fever', Bulletin of the History of Medicine, 52, 1 (1978)

Gordon, Lord Adam, 'Journal of an officer who travelled in America and the West Indies in 1764 and 1765', in N. D. Meereness (ed.), Travels in the American colonies, New York, 1916

Gordon, J. F. S., Glasgow: ancient and modern, Glasgow, 1872

Gould, Eliga H., 'American independence and Britain's counter-revolution', Past and Present, 154 (1997), 107-141

Gould, Eliga H., 'A virtual nation: Greater Britain and the imperial legacy of the American Revolution', American Historical Review, 104, 2 (1999), 476-89

Gould, Eliga H., The persistence of empire: British political culture in the era of the American Revolution, Chapel Hill, 2000

Goveia, Elsa V., Slave society in the British Leeward Islands at the end of the eighteenth century, New Haven, 1965

Graham, I. C. C., Colonists from Scotland: Emigration to North America, 1707-1783, Ithaca, 1956

Grainger, J., An essay on the more common West-India diseases; and remedies which that country itself produces, London, 1764

Grant, A., and Stringer, K. J. (eds), Uniting the kingdom? The making of British history, London, 1995

Grant, F. J. (ed.), Register of marriages in the city of Edinburgh, Edinburgh, 1922

Gray, Malcolm, 'Scottish migration: The social impact of agrarian change in the rural lowlands, 1775-1875', Perspectives in American History, 7 (1973), 95-176 


\section{BIBLIOGRAPHY}

Gray, Malcolm, Scots on the move: Scottish migrants 1750-1914, Edinburgh, 1990

Greene, Jack P., 'Changing identity in the British Caribbean: Barbados as a case study', in N. Canny and A. Pagden (eds), Colonial identity in the Atlantic world, 1500-1800, Princeton, 1987

Greene, Jack P., Pursuits of happiness: The social development of early modern British colonies and the formation of American culture, Chapel Hill and London, 1988

Greene, Jack P., 'The Jamaica privilege controversy, 1764-66: An episode in the process of constitutional definition in the early modern British Empire', Journal of Imperial and Commonwealth History, 22, 1 (1994), 15-63

Griffin, Patrick, The people with no name: Ireland's Ulster Scots, America's Scots Irish, and the creation of a British Atlantic world, 1689-1764, Princeton and Oxford, 2001

Griffiths, N. E. S., and Reid, J. G., 'New evidence on New Scotland, 1629', William and Mary Quarterly, 49, 3 (1992), 492-508

Grove, Richard H., Green imperialism: Colonial expansion, tropical island edens and the origins of environmentalism, 1600-1800, Cambridge 1995

Habermas, Jurgen, The structural transformation of the public sphere, London, 1989

Hall, Douglas (ed.), In miserable slavery: Thomas Thistlewood in Jamaica, 1750-1786, London, 1989

Hamilton, David, The healers: A history of medicine in Scotland, Edinburgh, 1981

Hamilton, Douglas J., 'Patronage and profit: Scottish networks in the British West Indies, c. 1763-1807', PhD thesis, University of Aberdeen, 1999

Hamilton, Douglas, 'Private enterprise and public service: Naval contracting in the Caribbean, 1720-50', Journal for Maritime Research (April 2004), www.jmr.nnm.ac.uk

Hamilton, H., 'The founding of the Glasgow Chamber of Commerce, 1783', Scottish Journal of Political Economy, 1 (1954), 33-48

Hancock, David, Citizens of the world: London merchants and the integration of the British Atlantic community, 1735-1785, Cambridge, 1995

Hancock, David, 'Commerce and conversation in the eighteenth-century Atlantic: The invention of Madeira wine', Journal of Interdisciplinary History, 39, 2 (1998), 197-219

Hancock, David, 'The British Atlantic world: coordination, complexity, and the emergence of an Atlantic market economy, 1651-1815', Itinerario, 23, 2 (1999), 107-26

Hargreaves, John D., Aberdeenshire to Africa: Northeast Scots and British overseas expansion, Aberdeen, 1981

Harlow, V., and Madden, F., British colonial development, 1774-1834: Select documents, Oxford, 1953

Harper, Marjory, Emigration from north-east Scotland, vol. 1: Willing exiles, Aberdeen, 1988 


\section{BIBLIOGRAPHY}

Harris, Bob, "American idols': Empire, war and the middling ranks in mideighteenth-century Britain', Past and Present, 150 (1996), 111-43

Henige, D. P. (ed.), Colonial governors from the fifteenth century to the present, Madison, 1970

Hibbert, Christopher, King Mob: The story of Lord George Gordon and the riots of 1780, London, 1958

Higman, Barry W., 'The West India "interest" in Parliament, 1807-1833', Historical Studies, 13, 1 (1967), 1-19

Higman, Barry W. (ed.), Trade, government and society in Caribbean history, 1700-1920, Kingston, 1983

Hobsbawm E., and Ranger, T. (eds), The invention of tradition, Cambridge, 1983

Hook, Andrew, Scotland and America: A study of cultural relations, 1750-1835, Glasgow and London, 1975

Hough, S. L., and Hough, P. R. O. (eds), The Beinecke Lesser Antilles collection at Hamilton College, 1521-1860, Gainesville, 1994

House of Assembly of Jamaica, Proceedings of the Honourable House of Assembly of Jamaica in the sugar and slave trade, London, 1793

Houston, R. A., 'The literacy myth? Illiteracy in Scotland, 1630-1760', Past and Present, 96 (1982), 81-102

Houston, R. A., and Whyte I. D. (eds), Scottish society, 1500-1800, Cambridge 1989

Hulme, P., and Whitehead, N. L. (eds), Wild majesty: Encounters with Caribs from Columbus to the present day, Oxford, 1992

Humboldt, Alexander von, Personal narrative of travels to the equinoctial regions of America, during the years 1799-1804, trans. T. Ross, London, 1852

Hunter, James, The making of the crofting community, Edinburgh, 1995

Hunter, P. W., Purchasing identity in the Atlantic world: Massachusetts merchants 1670-1780, Ithaca and London, 2001

Hyam, Ronald, 'Imperial interests and the Peace of Paris (1763)', in R. Hyam and G. Martin (eds), Reappraisals in British imperial history, London, 1975, 21-43

Inikori, J. E., Africans and the industrial revolution in England: A study in international trade and development, Cambridge, 2002

Inikori, J. E., and Engerman, S. L. (eds), The Atlantic slave trade, Durham, SC, 1992

Insh, George P., Scottish colonial schemes, 1620-1686, Glasgow, 1922

Israel, J. L., 'A conflict of empires: Spain and the Netherlands, 1618-1648', Past and Present, 76 (1977), 34-74

Jenkinson, J., Scottish medical societies, 1731-1939: Their history and records, Edinburgh, 1993

Judd, Gerrit P. (ed.), Members of Parliament, 1734-1832, New Haven, 1955

Karras, Alan L., 'The world of Alexander Johnston: The creolization of ambition, 1762-1787', Historical Journal, 30, 1 (1987), 53-76

Karras, Alan L., Sojourners in the sun: Scottish migrants in Jamaica and the Chesapeake, 1740-1800, Ithaca, 1992 


\section{BIBLIOGRAPHY}

Karras, A. L., and McNeill, J. R. (eds), Atlantic American societies: From Columbus through abolition, 1492-1888, London and New York, 1992

Kidd, Colin, 'North Britishness and the nature of eighteenth-century patriotism', Historical Journal, 39, 2 (1996), 361-82

Kidd, Colin, 'The ideological significance of Robertson's History of Scotland', in S. J. Brown (ed.), William Robertson and the expansion of empire, Cambridge, 1997

Laidlaw, Zoë, 'Networks, patronage and information in governance: Britain, New South Wales and the Cape Colony, 1826-1843', DPhil thesis, University of Oxford, 2001

Landsman, Ned C., Scotland and its first American colony, 1683-1765, Princeton, 1985

Landsman, Ned C., From colonials to provincials: American thought and culture, 1680-1760, New York, 1998

Landsman, Ned C., 'Nation, migration and province in the first British Empire: Scotland and the Americas, 1600-1800', American Historical Review, 104, 2 (1999), 463-75

Landsman, Ned C. (ed.), Nation and province in the first British Empire: Scotland and the Americas, 1600-1800, Lewisburg, PA, and London, 2001

Latimer, J., The history of the Society of Merchant Venturers of the city of Bristol, 1903; New York, 1970

Law, Robin, 'The first Scottish Guinea company, 1634-39', Scottish Historical Review, 76, 2 (1997), 185-202

Lawrence-Archer, J. H., Monumental inscriptions of the British West Indies, London, 1875

Lawson, Philip, The imperial challenge: Quebec and Britain in the age of the American Revolution, Montreal, 1989

Lenman, Bruce P., An economic history of modern Scotland 1660-1976, London, 1977

Lenman, Bruce P., Integration and Enlightenment: Scotland 1746-1832, Edinburgh, 1981

Lillywhite, Bryant (ed.), London coffee houses, London, 1963

Long, Edward, The history of Jamaica, or general survey of the antient and modern state of that island, 1774; London, 1970

Macinnes, Allan I., 'A strategy for history: Inaugural lecture', Aberdeen University Review, 192 (1994), 349-60

Macinnes, Allan I., Clanship, commerce and the House of Stuart, 1603-1788, East Linton, 1996

Macinnes, Allan I., 'Scottish Gaeldom from clanship to commercial landlordism, c. 1600-c. 1850', in S. Foster, A. I. MacInnes and R. McInnes (eds), Scottish power centres, Glasgow, 1999

Macinnes, Allan I., Harper, M. D., and Fryer, L. G. (eds), Scotland and the Americas: A documentary source book, Edinburgh 2002

MacKay, J., RB: A biography of Robert Burns, Edinburgh, 1992

MacKenzie, John M., 'Essay and reflection: On Scotland and the empire', International History Review, 15, 4 (1993), 714-39 


\section{BIBLIOGRAPHY}

MacKenzie, John M., Empires of nature and the nature of empires: Imperialism, Scotland and the environment, East Linton, 1997

MacKenzie, John M., 'Empire and national identities: The case of Scotland', Transactions of the Royal Historical Society, 6th series, 8 (1998), 215-31

Mackillop, A., and Murdoch S. (eds), Military governors and imperial frontiers c. 1600-1800: A study of Scotland and empires, Leiden, 2003

MacLaren, A. A., 'Patronage and professionalism: The 'forgotten middle class' 1760-1860', in D. McCrone et al. (eds), The making of Scotland: Nation, culture and social change, Edinburgh, 1989

MacLeod, R., and Lewis, M. (eds), Disease, medicine and power: Perspectives on western medicine and the experience of European expansion, London and New York, 1988

MacMillan, D. S., Scotland and Australia 1788-1850: Emigration, commerce and investment, Oxford, 1967

MacMillan, D. S., 'The 'new men' in action: Scottish mercantile and shipping operations in the North American colonies, 1760-1825', in D. S. MacMillan (ed.), Canadian business history: Selected studies, Toronto, 1972

Marshall, P., Bristol and the abolition of slavery, Bristol, 1975

Marshall, Peter J., 'Britain and the world in the eighteenth century, i: Reshaping the empire', Transactions of the Royal Historical Society, 6th series, 8 (1998), 1-18

Marshall, Peter J., 'Who cared about the Thirteen Colonies? Some evidence from philanthropy', Journal of Imperial and Commonwealth History, 27, 2 (1999), 52-67

Marshall, Peter J., 'Britain and the world in the eighteenth century, iv: The turning outwards of Britain', Transactions of the Royal Historical Society, 6th series, 11 (2001), 1-15

Marshall, Peter J. (ed.), The Oxford history of the British Empire, vol. 2: The eighteenth century, Oxford, 1998

Martin, R. M., History of the West Indies, comprizing Jamaica, Honduras, Trinidad, Tobago, Grenada, the Bahamas and the Virgin Isles, London, 1836

Matheson, D. L., 'Freemasonry in St Christopher's island 1739-1983', Year Book of the Grand Lodge of Antient Free and Accepted Masons of Scotland (1984), 78-80

Matthew, H. C. G., and Harrison, B. (eds), Oxford dictionary of national biography, Oxford, 2004

McCusker, J. J., and Morgan, K. (eds), The early modern Atlantic economy, Cambridge, 2001

McCusker, J. J., 'Weights and measures in the colonial sugar trade', William and Mary Quarterly, 30, 4 (1973), 599-624

McCusker, J. J., Money and exchange in Europe and America, 1660-1775, Chapel Hill, 1978

McCusker, J. J. (ed.), Essays in the economic history of the Atlantic world, London and New York, 1997 


\section{BIBLIOGRAPHY}

McDonald, Roderick A. (ed.), West Indies accounts: Essays on the history of the British Caribbean and the Atlantic economy in honour of Richard B. Sheridan, Barbados, 1996

McDonald, Roderick A. (ed.), Between slavery and freedom: Special Magistrate John Anderson's journal of St Vincent during the apprenticeship, Kingston and Philadelphia, 2001

McFarlane, Anthony, The British in the Americas 1480-1815, London, 1994

McGrath, Patrick (ed.), A Bristol miscellany, Bristol, 1985

Meinig, D. W., The shaping of America, vol. 1: Atlantic America, New Haven, 1986

Minchinton, W. E. (ed.), The trade of Bristol in the eighteenth century, Bristol, 1957

Minchinton, W. E., The port of Bristol in the eighteenth century, Bristol, 1962

Minchinton, W. E., Politics and the port of Bristol in the eighteenth century: The petitions of the Society of Merchant Venturers, Bristol, 1963

Mintz, Sidney, Sweetness and power: The place of sugar in modern history, New York, 1985

Mitchell, B. R., and Deane, P. (ed.), Abstract of British historical statistics, Cambridge, 1962

Mitchison, Rosalind, Agricultural Sir John: The life of Sir John Sinclair of Ulbster, 1754-1835, London, 1962

Morgan, A., The rise and progress of Scottish education, Edinburgh and London, 1927

Morgan, Kenneth, Bristol and the Atlantic trade in the eighteenth century, Cambridge, 1993

Morton, A. G., History of botanical science, London, 1981

Morton, A. G., John Hope, 1725-1786: Scottish botanist, Edinburgh, 1986

Mosley, C. (ed.), Burke's peerage and baronetage, Crans, 1999

Mouser, Bruce L., 'Trade, coasters and conflict in the Rio Pongo from 1790-1808', Journal of African History, 14, 1 (1973), 45-64

Mowat, I. R. W., Easter Ross 1750-1850: The double frontier, Edinburgh, 1981

Munck, W. (ed.), The roll of the Royal College of Physicians of London, 2 vols, London, 1878

Munn, Charles W., The Scottish provincial banking companies, 1747-1864, Edinburgh, 1981

Munro, R. W., and Munro, J., Tain through the centuries, Tain, 1966

Murdoch, Alexander, The people above: Politics and administration in mideighteenth-century Scotland, Edinburgh, 1980

Murdoch, Alexander, 'Lord Bute, James Stuart MacKenzie and the government of Scotland', in K. Schweizer (ed.), Lord Bute: Essays in re-interpretation, Leicester, 1988, 117-46

Murdoch, Alexander, British history 1660-1832: National identity and local culture, Basingstoke, 1998

Murdoch, D. H., 'Land policy in the eighteenth-century British Empire: The sale of Crown lands in the Ceded Islands, 1763-1783', Historical Journal, $27,3(1984), 549-74$ 


\section{BIBLIOGRAPHY}

Murdoch, Steve W., Britain, Denmark-Norway and the House of Stuart, 1603-60, East Linton, 2000

Namier, L., The structure of politics at the accession of George III, London, 1957

Namier, L., Crossroads of power: Essays on eighteenth-century England, London, 1962

Namier, L., and Brooke J. (eds), The History of Parliament: The House of Commons, 1754-1790, London, 1964

Nicolas, Armand, Histoire de la Martinique, des Arawaks à 1848, Paris and Montreal, 1996

Oliver, Vere L., Caribbeana, being miscellaneous papers relating to the history, genealogy, topography and antiquities of the British West Indies, 6 vols, London, 1909-19

Olson, Alison, G., 'The Board of Trade and London-American interest groups in the eighteenth century', Journal of Imperial and Commonwealth History, 8, 2 (1980), 33-50

O'Shaughnessy, Andrew J., 'The Stamp Act crisis in the British Caribbean', William and Mary Quarterly, 51, 2 (1994), 203-26

O'Shaughnessy, Andrew J., 'The formation of a commercial lobby: The West India interest, British colonial policy and the American Revolution', Historical Journal, 40, 1 (1997), 71-95

O'Shaughnessy, Andrew J., An empire divided: The American Revolution and the British Caribbean, Philadelphia, 2000

Pacquette, R. L., and Engerman, S. L. (eds), The Lesser Antilles in the age of European expansion, Gainesville, FL, 1996

Pares, Richard, A West-India fortune, London, 1950

Pares, Richard, 'The London sugar market, 1740-1769', Economic History Review, 9 (1956), 252-70

Pares, Richard, 'A London West India merchant house, 1740-69', in R. Pares and A. J. P. Taylor (eds), Essays presented to Sir Lewis Namier, London, 1956

Parker, Anthony W., Scottish Highlanders in colonial Georgia: The recruitment, emigration and settlement at Darien, 1735-1748, Athens, GA, 1997

Parry, J. H., 'The patent offices of the British West Indies', English Historical Review, 69 (1954), 200-25

Pearson, R., and Richardson, D., 'Business networking in the industrial revolution', Economic History Review, 54, 4 (2001), 657-79

Penson, Lillian M., 'The London West India interest in the eighteenth century', English Historical Review, 36 (1921), 373-92

Penson, Lillian M., The colonial agents of the British West Indies: A study in colonial administration, mainly in the eighteenth century', 1924; London, 1971

Phillipson, Nicholas, 'The Scottish Enlightenment', in R. Porter and M. Teich (eds), The enlightenment in national context, Cambridge, 1981

Phillipson, N., and Mitchison R. (eds), Scotland in the age of improvement, Edinburgh, 1970

Pine, L. G. (ed.), Burke's landed gentry, London, 1952 


\section{BIBLIOGRAPHY}

Pocock, J. G. A., 'British history: A plea for a new subject', New Zealand Journal of History, 8, 1 (1974), 3-21

Pocock, J. G. A., 'The limits and divisions of British history: In search of the unknown subject', American Historical Review, 87, 2 (1982), 311-36

Pocock, J. G. A., 'The new British history in Atlantic perspective: An Antipodean commentary', American Historical Review, 104, 2 (1999), 490-500

Pope, D. J., 'Shipping and trade in the port of Liverpool, 1783-1793', PhD thesis, University of Liverpool, 1970

Price, J. M., 'The rise of Glasgow in the Chesapeake tobacco trade, 1707-1775', William and Mary Quarterly, 11 (1954), 179-99

Price, J. M., Capital and credit in British overseas trade: The view from the Chesapeake, Cambridge, MA, 1980

Price, J. M., 'Buchanan \& Simson, 1759-63: A different kind of Glasgow firm trading to the Chesapeake', William and Mary Quarterly, 40, 1 (1983), 3-41

Price, J. M., 'What did merchants do? Reflections on British overseas trade, 1660-1790', Journal of Economic History, 44, 2 (1989), 267-84

Price, R., and Price, S. (eds), Stedman's Surinam: Life in an eighteenth-century slave society, Baltimore, 1992

Quier, John, et al., Letters and essays on the small pox and inoculation, London and Edinburgh, 1778

Quintanilla, Mark, 'The world of Alexander Campbell: An eighteenth-century Grenadian planter', Albion, 35, 2 (2003), 229-56

Ragatz, L. J., 'Absentee landlordism in the British Caribbean, 1750-1833', Journal of Agricultural History, 5, 1 (1931), 7-24

Ragatz, L. J., The fall of the planter class in the British Caribbean, 1763-1833, 1928; New York, 1981

Rice, C. Duncan, 'Abolitionists and abolitionism in Aberdeen: A test case for the nineteenth-century abolition movement', Northern Scotland, 1, 1 (1972), 65-87

Richards, Eric, A history of the Highland clearances, London, 1985

Richardson, D., 'The slave trade, sugar and British economic growth, 1748-1776', Journal of Interdisciplinary History, 17, 4 (1987), 739-70

Riddell, Maria, Voyages to the Madeira, and Leeward Caribbean islands, Edinburgh and London, 1792

Robertson, John, The Scottish Enlightenment and the militia issue, Edinburgh, 1985

Robertson, M. L., 'Scottish commerce and the American War of Independence', Economic History Review, 9 (1956), 123-31

Roby, John, Members of the assembly of Jamaica, from the institution of that branch of the legislature to the present time, Montego Bay, 1831

Rocher, R., and Scorgie, M. E., 'A family empire: The Alexander Hamilton cousins, 1750-1830', Journal of Imperial and Commonwealth History, 23, 2 (1995), 189-210

Roger, G. C., et al. (eds), The papers of Henry Laurens, Columbia, SC, 1968-92

Rollo, John, Observations on the means of preserving and restoring health in the West-Indies, London, 1783 


\section{BIBLIOGRAPHY}

Rosner, Lisa, Medical education in the age of improvement, Edinburgh, 1991

Rudé, George, 'The Gordon Riots: A study of the rioters and their victims', in G. Rudé, Paris and London in the eighteenth century, New York, 1971

Saville, Richard, Bank of Scotland: A history 1695-1995, Edinburgh, 1996

Schaw, Janet, Journal of a lady of quality, being the narrative of a journey from Scotland to the West Indies, North Carolina and Portugal in the years 1774 to 1776, ed. E. W. Andrews and C. M. Andrews, New Haven, 1923

Scott, H., Fasti eccelsiae Scoticanae, Edinburgh, 1928

Seal Coon, F., 'Scottish freemasonry in Jamaica', Year Book of the Grand Lodge of Antient Free and Accepted Masons of Scotland (1982), 100-3

Sedgwick, R. (ed.), Letters of George III to Lord Bute, 1756-1766, London, 1939

Seton, B. G., and Arnott, J. G., The prisoners of the 45, Edinburgh, 1928

Seymour, S., Daniels, S., and Watkins, C., 'Estate and empire: Sir George Cornewall's management of Moccas, Hertfordshire and La Taste, Grenada, 1771-1819', Journal of Historical Geography, 24, 3 (1998), 313-51

Shephard, Charles, An historical account of the island of St Vincent, London, 1831

Shepherd, Verene A., 'Pens and pen-keepers in a plantation society: Aspects of Jamaican economic and social history, 1740-1815', PhD thesis, University of Cambridge, 1988

Shepherd, Verene A. (ed.), Slavery without sugar: Diversity in Caribbean society and economy since the seventeenth century, Gainesville, FL, 2002

Sher, R. B., and Smitten, J. R. (eds), Scotland and America in the age of the Enlightenment, Edinburgh, 1990

Sheridan, Richard B., 'The commercial and financial organisation of the British slave trade, 1750-1807', Economic History Review, 11 (1958), 249-63

Sheridan, Richard B., 'The credit crisis of 1772 and the American colonies', Journal of Economic History, 20, 2 (1960), 161-86

Sheridan, Richard B., 'The rise of a colonial gentry: A case study of Antigua, 1730-1775', Economic History Review, 13, 3 (1961), 342-57

Sheridan, Richard B., 'The wealth of Jamaica in the eighteenth century', Economic History Review, 18, 2 (1965), 292-311

Sheridan, Richard B., Sugar and slavery: An economic history of the British West Indies, 1623-1775, Barbados, 1974

Sheridan, Richard B., 'The role of Scots in the economy and society of the West Indies', in V. Rubin and A. Tuden (eds), Comparative perspectives on slavery in New World plantations, New York, 1977

Sheridan, Richard B., Doctors and slaves: A medical and demographic history of slavery in the British West Indies, 1680-1834, Cambridge, 1985

Simmons, R. C., and Thomas, P. D. G. (eds), Proceedings and debates of the British parliaments respecting North America, 1754-1783, Millwood, NY, 1983

Simpson, Grant G. (ed.), Scotland and Scandinavia, 800-1800, Edinburgh,1990

Simpson, Grant G. (ed.), The Scottish soldier abroad, 1247-1967, Edinburgh, 1992

Simpson, Grant G. (ed.), Scotland and the Low Countries, 1124-1994, East Linton, 1996 


\section{BIBLIOGRAPHY}

Sinclair, Sir John, The statistical account of Scotland, 1791-1799, ed. D. J. Withrington and I. R. Grant, Wakefield, 1975-83

Slaven, Anthony, The development of the west of Scotland, 1750-1960, London, 1975

Smith, S. D., 'Merchants and planters revisited', Economic History Review, 15,3 (2002), 434-65

Smith, Woodruff D., 'Complications of the commonplace: Tea, sugar and imperialism', Journal of Interdisciplinary History, 23, 2 (1992), 25978

Smout, T. C., 'The early Scottish sugar houses, 1660-1720', Economic History Review, 14, 2 (1961), 240-53

Smout, T. C., 'Scottish landowners and economic growth, 1650-1850', Scottish Journal of Political Economy, 11 (1964), 218-34

Smout, T. C., A history of the Scottish people 1560-1830, London, 1969

Smout, T. C., Landsman, N. C., and Devine, T. M., 'Scottish migration in the seventeenth and eighteenth centuries', in N. Canny (ed.), Europeans on the move: Studies in European migration 1500-1800, Oxford, 1994

Sobel, Dava, Longitude, London, 1996

Sola-Corbacho, J. C., 'Family, paisanaje, and migration among Madrid's merchants (1750-1800)', Journal of Family History, 27, 1 (2002), 3-24

Solow, Barbara L. (ed.), Slavery and the rise of the Atlantic system, Cambridge, 1991

Stearns, R. P., 'Colonial fellows of the Royal Society of London, 1661-1778', William and Mary Quarterly, 3, 1 (1946), 208-68

Steele, Ian K., The English Atlantic 1675-1740: An exploration of communication and community, New York and Oxford, 1986

Stewart, J., A view of the past and present state of the island of Jamaica, 1823; New York, 1969

Stone, L. (ed.), An imperial state at war, London and New York, 1994

Strang, J., Glasgow and its clubs, or glimpses of the condition, manners, characters and oddities of the city, during the past and present century, London and Glasgow, 1856

Sumpter, E., The British antidote to the Caledonian poison, consisting of the most satirical prints for the year 1762-3, London, 1763

Sunter, Ronald M., Patronage and politics in Scotland, 1707-1832, Edinburgh, 1986

Taylor, C. (ed.), 'Journeys through the Caribbean', unpublished transcript, IHR

Thomas, P. D. G., British politics and the Stamp Act crisis: The first phase on the American Revolution, 1763-67, Oxford, 1975

Thomas, Robert P., 'The sugar colonies of the old empire: Profit or loss for Great Britain?', Economic History Review, 21, 1 (1968), 30-45

Thorne, R. G. (ed.), The History of Parliament: The House of Commons, 1790-1820, London, 1986

Thornton, A. P., West India policy under the Restoration, Oxford, 1956

Tilly, Charles, 'Transplanted networks', in V. Yans-McLaughlin (ed.), Immigration reconsidered: History, sociology and politics, New York and Oxford, 1990 


\section{BIBLIOGRAPHY}

Timperley, L. A. (ed.), A directory of landownership in Scotland, c. 1770, Edinburgh, 1976

Turnbull, G., Letters to a young planter, or observations on the management of a sugar plantation, London, 1785

Vance, James, 'Constitutional radicalism in Scotland and Ireland in the age of the American Revolution, c. 1760-1789', PhD thesis, University of Aberdeen, 1998

Walvin, James, Black ivory: A history of British slavery, London, 1992

Walvin, James, Fruits of empire: Exotic produce and British taste, 1660-1800, Basingstoke, 1997

Ward, J. R., West Indian slavery, 1750-1834: The process of amelioration, Oxford, 1988

Ward, J. R., 'The industrial revolution and British imperialism, 1750-1850', Economic History Review, 47, 1 (1994), 44-65

Watson, Charles B. B. (ed.), Register of Edinburgh apprentices, 1666-1755, Edinburgh, 1929

Watson, M., 'The British West Indian legislatures in the seventeenth and eighteenth centuries: An historiographical introduction', in P. Lawson (ed.), Parliament and the Atlantic empire, Edinburgh 1995

Watts, Sheldon, Epidemics and history: Disease, power and imperialism, New Haven, 1997

Williams, Eric, Capitalism and slavery, Chapel Hill, 1945

Williamson, John, Medical and miscellaneous observations, relative to the West India islands, Edinburgh, 1817

Wilson, Kathleen, 'Inventing revolution: 1688 and eighteenth-century popular politics', Journal of British Studies, 28 (1989), 349-86

Wilson, Kathleen, The sense of the people: Politics, culture and imperialism in England, 1715-1785, Cambridge, 1995

Withers, Charles W. J., 'Improvement and Enlightenment: Agriculture and natural history in the work of the Rev. John Walker (1731-1801)', in P. Jones (ed.), Philosophy and science in the Scottish Enlightenment, Edinburgh, 1988

Wood, Marguerite (ed.), Register of Edinburgh apprentices, 1756-1800, Edinburgh, 1963

Wood, P. B., The Aberdeen Enlightenment: The arts curriculum in the eighteenth century, Aberdeen, 1993

Wright, W., 'Description and use of the cabbage-bark tree of Jamaica', Philosophical Transactions of the Royal Society, 67 (December 1777), 507-11

Wright, W., 'Description of the Jesuits bark tree', Philosophical Transactions of the Royal Society. 67 (December 1777), 504-6

Young, William, Considerations which may tend to promote the settlement of our new West-India colonies, by encouraging individuals to embark on the undertaking, London, 1764

Zacek, Natalie, A., 'Sex, sexuality, and social control in the eighteenth-century Leeward Islands', in M. D. Smith (ed.), Sex and sexuality in colonial America, 1492-1800, New York, 1998

Zuckerman, Michael, 'The fabrication of identity in early America', William and Mary Quarterly, 34, 2 (1977), 183-214 
Douglas J. Hamilton - 9781847793034 Downloaded from manchesterhive.com at 04/26/2023 09:54:53AM via free access 